\title{
EXERGY AND ECONOMIC ANALYSES OF METHANOL PRODUCTION PROCESS
}

\author{
J. O. Odejobi1 ${ }^{1,}$ and O. S. Ayorinde ${ }^{2}$ \\ 1,2, APPlied Thermodynamics and Process Design Lab., OBAfEmi Awolowo UniV., Ile-IFe, OSUn State. NIGERIA \\ E-mail addresses:1 dareodejobi@oauife.edu.ng, 2 ola4dam37@gmail.com
}

\begin{abstract}
A process that utilized $\mathrm{CO}_{2}$ recovered from thermal power plant flue gas for methanol production was simulated using Aspen HYSYS V8.4 software. Exergy and economic analyses approaches were used to determine the optimum number of trays in the distillation column for economic operation of the process. The results from both approaches showed that the optimum numbers of trays were 20 and further increase in the number of trays did not yield any significant improvement in the process efficiency and quality of methanol produced. The profitability analysis of the plant showed a payback period of 3 years. The study concluded that locating such plant close to the thermal power plant will mitigate the emission of $\mathrm{CO}_{2}$ by providing onsite utilization for the $\mathrm{CO}_{2}$ emitted and captured from the thermal power plant.
\end{abstract}

Keywords: $\mathrm{CO}_{2}$ capture; methanol production; exergy analysis; economic analysis

\section{INTRODUCTION}

Many industrial manufacturing processes like synthesis gas manufacture, combustion processes etc. emit carbon dioxide to the atmosphere [1]. Carbon dioxide, one of the main causes of global warming, released from such combustion of fossil fuels and other manufacturing processes contributes to an increase in the concentration of greenhouse gas emissions (GHG) in the atmosphere [2]. These emissions could be mitigated by using different methods such as enhancement of energy efficiency of equipment, replacement of fossil fuel sources with renewable energy sources and transformation of emitted carbon dioxide to other valuable raw materials of which methanol is one [3]. Of all these techniques, converting carbon dioxide to other valuable raw materials has been identified as the most viable [4]. The investigation of carbon dioxide as a carbon source for chemical production and fuel synthesis has received enormous attention. It was discovered from such investigation that the recovery of carbon dioxide from thermal power plant could contribute significantly to reducing climate change $[3,5]$.

Methanol is a volatile, poisonous and colorless liquid used as antifreeze, solvent, fuel, denaturant for ethyl alcohol and feedstock to produce formaldehyde, methyl tertiary butyl ether (MTBE) and acetic acid [6]. It is also a chemical reactant in a number of important chemical syntheses and recently, methanol is of large industrial significance, it has become a widely used raw material for the development of fuel cell technologies, particularly direct methanol fuel cells (DMFC) [7].

The global production of methanol was around 85 million metric tons in 2012 [8] with the annual production exceeds 40 million tons and continues to grow by $4 \%$ per year, and this is expected to continue at about the same pace [9]. The growth is due to the recent research that showed methanol as one of the best potential renewable energy sources to replace gasoline with minimal environmental impact [10].

A few number of works have been done on the upgrade of $\mathrm{CO}_{2}$ to methanol $[11,12]$. Feasibility of methanol production from flue gas with the aim of reducing carbon dioxide emissions level and increasing the level of renewable energy supply has been studied [10]. The study highlighted the benefits of successful development and implementation of the production process and its impact on reducing the level of carbon dioxide emissions into the atmosphere. Methanol synthesis from carbon dioxide and hydrogen in order to mitigate carbon dioxide mitigation has been reported [13]. In the study, highly efficient $\mathrm{Cu} / \mathrm{ZnO}$ based material catalysts were investigated and the durability of the catalysts was achieved by adding a small quantity of silica to the catalysts. The study showed that the addition of silica caused the catalysts to be repressed in the crystallization of $\mathrm{ZnO}$ while 
the catalysts were very active and exceedingly stable in methanol synthesis from carbon dioxide and hydrogen. Although methanol production process has been studied since the 1920s, there is lack of studies related to the economic and exergy analyses of the whole production process. The need to capture carbon dioxide emissions from thermal power plant and create a valuable uses for it is an economic mitigation measure to control the hazardous impact it has on the environment. This research work therefore focused on the development of process for the utilization of the carbon dioxide emitted from the thermal power plant for the production of methanol. The simulation and exergy analysis of the process are done to identify potential areas where useful energy losses could occur within the process. The effects of variation of process parameters on the plant performance are investigated, economic evaluation of the process is done to identify cost-effective operation of the process and the profitability analysis is done using payback period as economic index.

\section{PROCESS DESCRIPTION}

The four stages involved in the production of methanol include feed preparation, steam reforming, methanol synthesis and methanol distillation. In the methanol production process, the feed stream comprises natural gas, steam and carbon dioxide captured from the flue gas emitted from thermal power plant. The natural gas stream initially enters the desulfurization unit to remove the sulphur compounds that may be present as impurities in the stream. Before the water is converted to steam and added to the process, the impurities present in the water stream are reduced to undetectable or parts per billion levels [14]. The reforming process transforms the methane and the steam to intermediate reactants of hydrogen, carbon dioxide and carbon monoxide. Carbon dioxide is also added to the feed gas stream at the methanol synthesis stage to produce a mixture of components in the ideal ratio to efficiently produce methanol. The reactants are converted to methanol and separated out as crude product which is then purified in distillation columns. The captured $\mathrm{CO}_{2}$ is used up in the process, thereby mitigates emission of $\mathrm{CO}_{2}$ from the thermal power plant to the environment. A schematic diagram of the methanol production process is shown in Figure 1.

\section{THEORY}

\subsection{Methanol Production Reaction}

The overall methanol production process may be divided into two principal sections, namely, auto thermal reforming and methanol synthesis.

\subsubsection{Auto Thermal Reforming}

Partial oxidation of the fuel is conducted in the auto thermal reforming (ATR) in order to produce the heat required for the endothermic reforming reactions of the fuel. In the auto thermal process, oxygen added to generate heat is chemically bound in the product gas, which results that the $\mathrm{H}_{2} / \mathrm{CO}$ ratio in the product gas is lower than in other processes. While the oxidation reaction is used to adjust synthetic ratio, the typical operating conditions for this reaction are $850-1000{ }^{\circ} \mathrm{C}$ and $20-100$ bar [10]. The auto thermal reforming process model in this work takes into account the following principal reactions, in which three of the reactions are conversion reactions and one is equilibrium reaction.

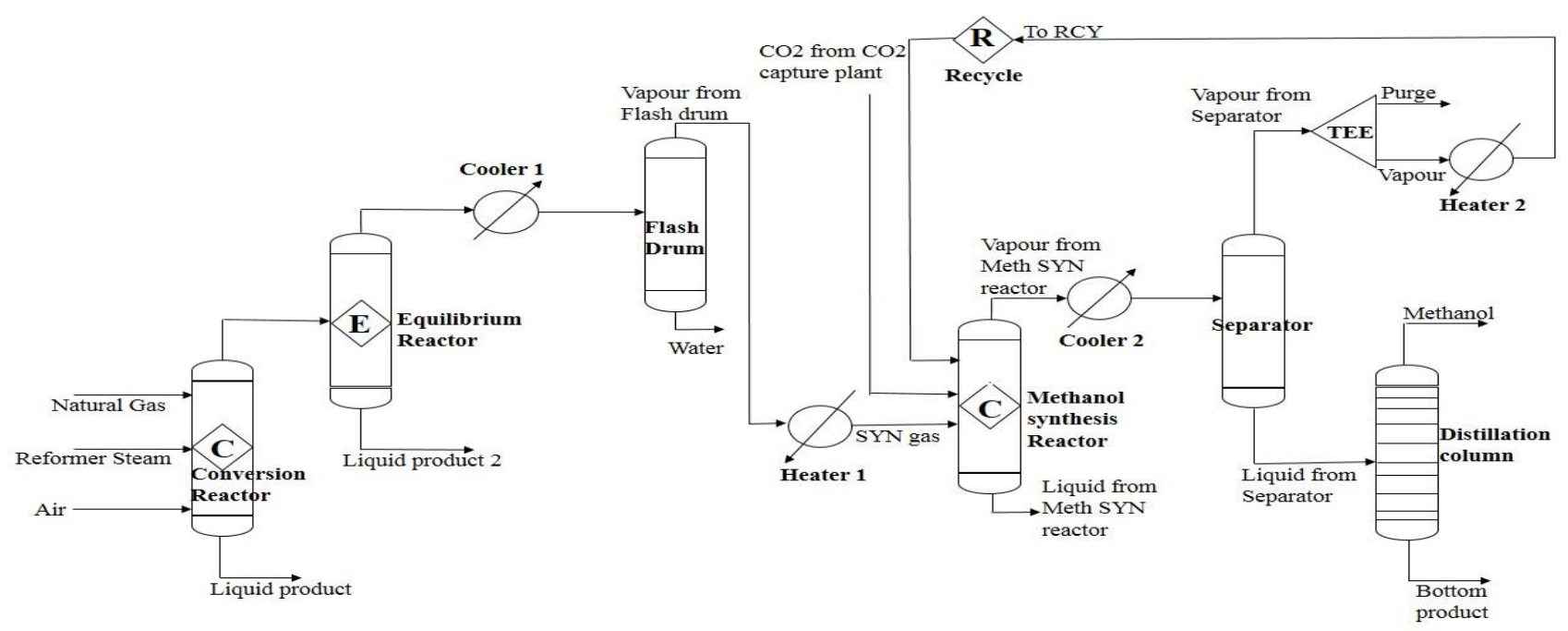

Figure 1: Schematic diagram of Methanol Process plant 
The reforming reactions:

$$
\begin{array}{r}
\mathrm{CH}_{4}+\mathrm{H}_{2} \mathrm{O} \rightarrow \mathrm{CO}+3 \mathrm{H}_{2} \\
\mathrm{CH}_{4}+2 \mathrm{H}_{2} \mathrm{O} \rightarrow \mathrm{CO}_{2}+4 \mathrm{H}_{2}
\end{array}
$$

The combustion reaction:

$$
\mathrm{CH}_{4}+2 \mathrm{O}_{2} \rightarrow \mathrm{CO}_{2}+2 \mathrm{H}_{2} \mathrm{O}
$$

The equilibrium reaction which is the water-gas shift reaction:

$$
\mathrm{CO}+\mathrm{H}_{2} \mathrm{O} \rightleftharpoons \mathrm{CO}_{2}+\mathrm{H}_{2}
$$

\subsubsection{Methanol Synthesis}

In the first step, the thermal decomposition step yields elemental carbon (in solid form) and large amounts of hydrogen gas as follows:

$$
3 \mathrm{CH}_{4} \rightarrow 3 \mathrm{C}+6 \mathrm{H}_{2}
$$

In the second step of the process, the hydrogen gas produced is fed into the methanol synthesis reactor where it is combined with carbon dioxide captured from the thermal power plant in a catalyzed reaction to produce methanol as follows:

$$
\mathrm{CO}_{2}+3 \mathrm{H}_{2} \rightarrow \mathrm{CH}_{3} \mathrm{OH}+\mathrm{H}_{2} \mathrm{O}
$$

Methanol resulting from this process is synthesized from carbon dioxide captured from the thermal power plant and hydrogen, as detailed in reaction 6, rather than by the more conventional combination of hydrogen and carbon monoxide (in a 2:1 molar ratio). The crude methanol formed during the methanol synthesis can then be distilled to remove water and other byproducts.

It should be noted that methanol is produced from syngas using $\mathrm{Cu} / \mathrm{ZnO}$ catalyst on an alumina oxide support and possible catalyst poisons include sulphur compounds, chlorine containing compounds and alkali metals. Poisoning by these compounds results in active site blocking or sintering, which yields decreased activity or change in selectivity of the catalyst. Hence, catalyst guard beds need to be installed for removal of these compounds.

\section{METHODOLOGY}

\subsection{Methanol Process Plant Simulation}

Methanol production process via synthesis gas is simulated using Aspen HYSYS V8.4 simulation tool. The thermodynamics for this process is described by SoaveRedlich-Kwong (SRK) fluid package available in the software. The carbon dioxide captured from the thermal power plant is used as $\mathrm{CO}_{2}$ source in this process [5].

\subsection{Exergy Analysis}

Exergy analysis enables the identification of locations, types and magnitudes of energy wastage and losses within the process for possible improvement in process performance and efficiency. It uses the principles of conservation of mass and energy together with the second law of thermodynamics [15]. The specific total exergy of a stream of material, $j$ neglecting the potential and kinetic energy terms consists of the physical exergy and the chemical exergy terms given as:

$$
E x_{j}^{\text {Total }}=E x_{j}^{\text {Phy }}+E x_{j}^{\text {Chem }}
$$

Physical exergy as given by Equation (10) equals to maximum amount of work obtainable when the system is brought from its actual state to the reference state with environment defined by $P_{o}$ and $T_{o}$ [16].

$$
E x_{j}^{\text {Phy }}=E x_{i}-E x_{o}=\left(H_{i}-H_{o}\right)-T_{o}\left(S_{i}-S_{o}\right)
$$

where: $H_{\mathrm{i}}$ and $S_{i}$ are the specific enthalpy and entropy, respectively at system temperature, $T_{i}$ and pressure, $P_{i}$. $H_{o}$ and $S_{o}$ are the specific enthalpy and entropy, respectively at reference temperature, $T_{o}$ and pressure, $P_{o}$.

The chemical exergy takes into consideration the mixing of a substance due to heat transfer, heat exchange and chemical reaction taking place in the system. The molar chemical exergy of an ideal mixture is given as [17]:

$$
E x_{j}^{C h e m}=\sum_{m=1}^{j} y_{m} e_{m}^{-C H}+R T_{o} \sum_{m=1}^{j} y_{m} \text { Iny } y_{m}
$$

where: $y_{m}$ is the is the mole fraction of component $m$

and $R$ is the universal gas constant taken as 8.314 $\mathrm{kJ} / \mathrm{kmol.K} ; e_{m}^{-C H}$ is standard molar chemical exergy (kJ/kmol) of various substances at $T_{o}$ and $P o[17]$.

The exergy rate of a stream of material $j$ was obtained from its specific value as:

$$
\dot{E x_{j}}=\dot{m}_{j} E x_{j}^{\text {Total }}
$$

where: $\dot{m}_{j}$ is the mass flow rate of material stream, $j$

Thus the unit and overall exergetic efficiency was defined, according to by Eqs. (13a and $b$ ) as $[18,19]$ :

$$
\begin{gathered}
\Psi_{\text {unit }}=\frac{\sum \dot{E} x_{\text {sink }}}{\sum \dot{E} x_{\text {source }}} \\
\Psi_{\text {overall }}=\frac{\sum E x_{\text {out }}}{\sum E x_{\text {in }}}
\end{gathered}
$$

The irreversibility which is a measure of exergy destruction due to entropy generation is calculated by setting up the exergy balance and taking the difference between all incoming and outgoing exergy flows as [20]:

$$
I=\sum E x_{\text {in }}-\sum E x_{\text {out }}
$$


4.3 Investigation of the Effects of Operating Parameters on the Process Performance and Economic Analyses of the Plant

The parametric study was performed on the process to establish the best and economically viable operating conditions that meet the specific demands from different clients, depending on the purity and purpose for which the methanol to be produced is intended to be used. Due to unavailability of literature materials on bare cost curve for most of the equipment used in the process, the equipment cost from Aspen HYSYS V8.4 was used as the purchased cost of equipment (PCE) for the cost estimation. The economic basis for the calculations involved an objective function that summed the capital and energy costs of the process assuming a useful life, $N$, of 25 years and an annual interest rate, $j$, of $12 \%$ [21]. The detailed factorial method for capital cost estimation provided in Table 1is used for the plant costing [22].

Physical plant cost (PPC) of methanol plant

$$
=\text { PCE of Methanol Plant } \mathrm{x}\left(1+\sum F_{I}\right)
$$

Fixed capital cost of methanol plant

$$
(\mathrm{FCC})=\mathrm{PPC} \times 1+F 10+F 11+F 12 \ldots
$$

The purchased cost of each equipment unit used in the process is presented in Table 2. The fixed capital cost of the methanol process was amortized over the useful life of the plant using Eq. (17) [23]:

Annualized fixed capital cost, $\mathrm{A}^{\mathrm{r}}$ is given by:

$$
\mathrm{A}^{\mathrm{r}}=\operatorname{FCC}\left[\frac{J(1+J)^{N}}{(1+J)^{N}-1}\right]
$$

Electricity was assumed to be the major source of power supply to the plant, hence the annual energy consumption in the process is estimated as:

Annual energy consumption

$$
\begin{aligned}
& =\text { Energy consumption }(\mathrm{kW}) \\
& \times \text { Operating time/year }(\mathrm{kWh} \\
& / \mathrm{yr})
\end{aligned}
$$

Daily energy consumption

$=$ Total power wattage of the plant $(\mathrm{kW} /$ day $)$

Annual cost of electricity

$$
\begin{aligned}
& =\text { Annual energy consumption }(\mathrm{kWh} \\
& / \mathrm{yr}) \times \text { Unit cost of electricity }(\$ \\
& / \mathrm{kWh})
\end{aligned}
$$

The plant was assumed to operate for 7200 hours per year and the unit cost of electricity is estimated to be $\$ 0.12 / \mathrm{kWh}$ at the exchange rate of $\$ 1$ to $\$ 160$. The profitability analysis of the process is evaluated using payback period as economic index.

$$
\begin{aligned}
& \text { Payback Period (yr) } \\
& =\frac{\text { Fixed Capital Cost of the Plant }(\$)}{\text { Net Profit Value (\$yr) }}
\end{aligned}
$$

\begin{tabular}{|c|c|c|c|c|}
\hline \multirow{2}{*}{$\mathrm{S} / \mathrm{N}$} & \multirow{2}{*}{ ITEM } & \multicolumn{3}{|c|}{ PROCESS TYPE } \\
\hline & & Fluids & Fluids-Solids & Solids \\
\hline \multirow{10}{*}{1} & Major equipment, total purchase cost & PCE & PCE & PCE \\
\hline & $f_{1}$ Equipment erection & 0.4 & 0.45 & 0.50 \\
\hline & $f_{2}$ Piping & 0.70 & 0.45 & 0.20 \\
\hline & $f_{3}$ Instrumentation & 0.20 & 0.15 & 0.10 \\
\hline & $f_{4}$ Electrical & 0.10 & 0.10 & 0.10 \\
\hline & $f_{5}$ Buildings, process & 0.15 & 0.10 & 0.05 \\
\hline & $f_{6}$ Utilities & 0.50 & 0.45 & 0.25 \\
\hline & $f_{7}$ Storages & 0.15 & 0.20 & 0.25 \\
\hline & $f_{8}$ Site development & 0.05 & 0.05 & 0.05 \\
\hline & $f_{g}$ Ancillary buildings & 0.15 & 0.20 & 0.30 \\
\hline \multirow{3}{*}{2} & Total physical plant cost (PPC) & & & \\
\hline & $\mathrm{PPC}=\mathrm{PCE}\left(1+f_{1}+\ldots .+f_{9}\right)$ & & & \\
\hline & $=$ Purchased Cost of Equipment (PCE) $\mathrm{x}$ & 3.40 & 3.15 & 2.80 \\
\hline \multirow{3}{*}{3} & $f_{10}$ Design and Engineering & 0.30 & 0.25 & 0.20 \\
\hline & $f_{11}$ Contractor's fee & 0.05 & 0.05 & 0.05 \\
\hline & $f_{12}$ Contingency & 0.10 & 0.10 & 0.01 \\
\hline 4 & Fixed capital $=$ PPC $\left(1+f_{10}+f_{11}+f_{12}\right)=$ PPC $x$ & 1.45 & 1.40 & 1.35 \\
\hline
\end{tabular}

\section{RESULTS AND DISCUSSION}

\subsection{Exergy Analysis of Methanol Production Plant}

The Aspen HYSYS V8.4 simulation model for the process is presented in Figure 2. Table 3 shows the results of estimated exergy source, exergy sink, exergitic efficiency and irreversibility for each process unit.

Table 1: Typical Factors for Estimation of Project Fixed Capital Cost

Source: [20] 
Table 2: Purchased cost of equipment for the methanol plant cost estimation

\begin{tabular}{llll}
\hline S/N & Equipment & Purchased Cost of Equipment (\$) & Quantity \\
\hline 1 & Auto thermal reactor (ATR) & 21100 & 1 \\
2 & Methanol synthesis reactor & 21100 & 1 \\
3 & Equilibrium reactor (ERV -100) & 21100 & 1 \\
4 & Separator (V-100 & 20000 & 1 \\
5 & Flash drum separator & 20000 & 1 \\
6 & Heater (E-101 and E-103) & 8300 & 2 \\
7 & Cooler (E-100 and E-102 & 8800 & 2 \\
8 & Distillation column (T-100) & 68900 & 1 \\
\end{tabular}

Source: Aspen HYSYS V8.4 Equipment Cost Analysis (2013)

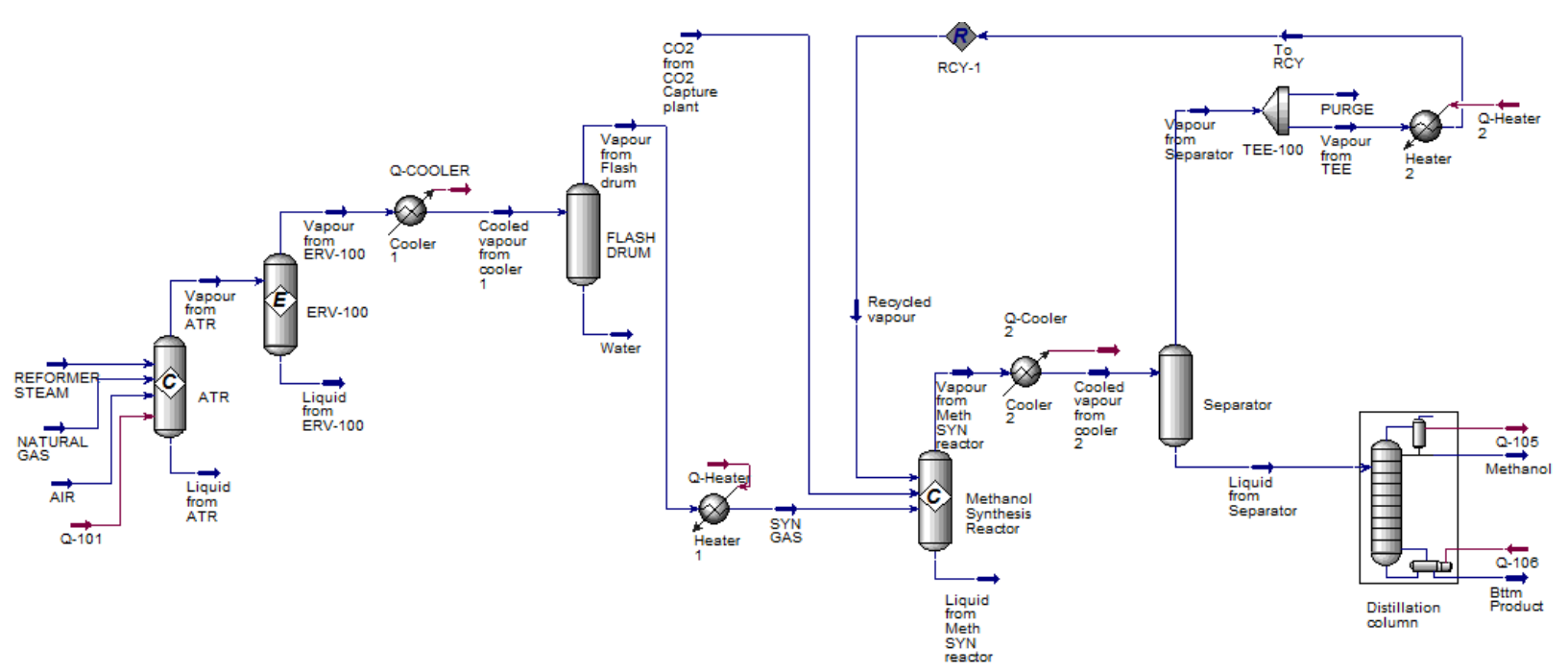

Figure 2: Simulation of Methanol Process plant

Table 3: The plant components exergy source, exergy sink, exergy efficiency, irreversibility and their percentage contributions to irreversibilities for methanol production process

\begin{tabular}{|c|c|c|c|c|c|}
\hline Component & $\begin{array}{c}\text { Ex source } \\
(\mathrm{kW})\end{array}$ & $\begin{array}{c}\text { Ex sink } \\
(\mathrm{kW})\end{array}$ & $\begin{array}{c}\text { Exergetic } \\
\text { efficiency }(\%)\end{array}$ & $\begin{array}{l}\text { Irreversibili } \\
\text { ty }(\mathrm{kW})\end{array}$ & $\begin{array}{l}\% \text { contribution to } \\
\text { irreversibility }\end{array}$ \\
\hline Auto thermal reactor (ATR) & 11867.2 & 4999.3 & 42.1 & 6867.9 & 27.0 \\
\hline Equilibrium reactor (ERV-100) & 2070.7 & 708.7 & 34.2 & 1362.1 & 5.4 \\
\hline Flash Drum & 1618.0 & 1290.0 & 79.7 & 328.0 & 1.3 \\
\hline Cooler 1 & 1556.1 & 451.2 & 29.0 & 1104.9 & 4.3 \\
\hline Heater 1 & 2124.7 & 745.6 & 35.1 & 1379.1 & 5.4 \\
\hline $\begin{array}{l}\text { Methanol Synthesis Reactor } \\
(\text { ERV-100) }\end{array}$ & 6777.3 & 5233.2 & 77.2 & 1544.0 & 6.1 \\
\hline Cooler 2 & 3261.1 & 813.5 & 24.9 & 2447.6 & 9.6 \\
\hline Separator (V-100) & 1641.9 & 1387.2 & 84.5 & 254.7 & 1.0 \\
\hline Distillation Column & 13882.2 & 6913.2 & 49.8 & 6969.0 & 27.4 \\
\hline TEE-100 & 6333.8 & 3556.1 & 56.1 & 2777.7 & 10.9 \\
\hline \multirow[t]{2}{*}{ Heater 2} & 3613.0 & 3213.2 & 88.9 & 399.8 & 1.6 \\
\hline & & & & 25434.8 & 100.0 \\
\hline
\end{tabular}

It could be seen from the table that the heater 2 has the highest exergetic efficiency of $88.9 \%$. The cooler 1 and cooler 2 have the lowest exergy efficiency of $29.0 \%$ and $24.9 \%$, respectively. The highest irreversibilty (exergy losses) of $6969.0 \mathrm{~kW}$ occurred in the distillation column. This is followed by autothermal 
reactor (ATR) which has irreversibility of $6867.9 \mathrm{~kW}$. The contribution of distillation column and the auto thermal reactor to overall plant irreversibilities are $27.4 \%$ and $27.0 \%$, respectively. Consequently, these two components are the highest sources of exergy losses in the process.

The high exergy destruction in the distillation column could be due to heat transfer and mixing associated with separation within the column. In the reformer, the exergy losses could be associated with the chemical reactions (steam reforming and combustion) and heat transfer from combustion products to the hydrocarbon/water mixture in the tubes [24]. Friction and heat losses could also be responsible for the losses. The closer the occurrence of chemical reactions to the thermodynamic equilibrium, the lower are the irreversibilities.

By preventing immediate contact of fuel with oxygen and using intermediate chemical reactions, irreversibilities in a combustion process can be reduced. The exergy destruction or irreversibilty associated with the reforming reaction can be reduced by preheating the hydrocarbon and the steam and by mixing the reactants at equal temperature and pressure [24].

\subsection{Results of Overall Exergy Efficiency of the Methanol Plant}

The results of overall exergy efficiency and irreversibility for varying number of trays in the distillation column are presented in Figure 3. It could be observed from the figure that the overall exergy efficiency increases and the overall irreversibility decreases as the number of tray increases. This is because with increasing number of tray the pressure drop within the column increased and the entropy generation due to liquid mixing resulting from separation within the column reduced. Hence, overall exergy efficiency increases while the overall irreversibility reduces with increasing number of trays. This observation was significant up to when the number of trays in the distillation column were twenty (20). Above this point, effect of increasing number of trays on overall exergy efficiency and irreversibility was no longer significant. These results showed that the optimum number of trays for economic operation of the distillation column was 20, above which the operation of the process is no longer profitable.

\subsection{Effect of Reflux Ratio on the Distillate Rate and Methanol Purity}

The results of variation of reflux ratio from 0.7 to 1.4 on distillate rate and methanol purity are presented in Figure 4. It could be observed from the figure that the distillate rate reduced with increasing reflux ratio while the methanol purity was increased. In distillation operation, higher reflux ratio is usually used to obtain high purity methanol product [25]. However, sustaining this high reflux ratio could increase the operation cost because of high reboiler and condenser heat duty requirements [26]. The results showing effect of increasing number of trays on both the reboiler and condenser heat duties are presented in Figure 5. It could be observed from the figure that both the reboiler and condenser heat duties are increasing with increasing reflux ratio.

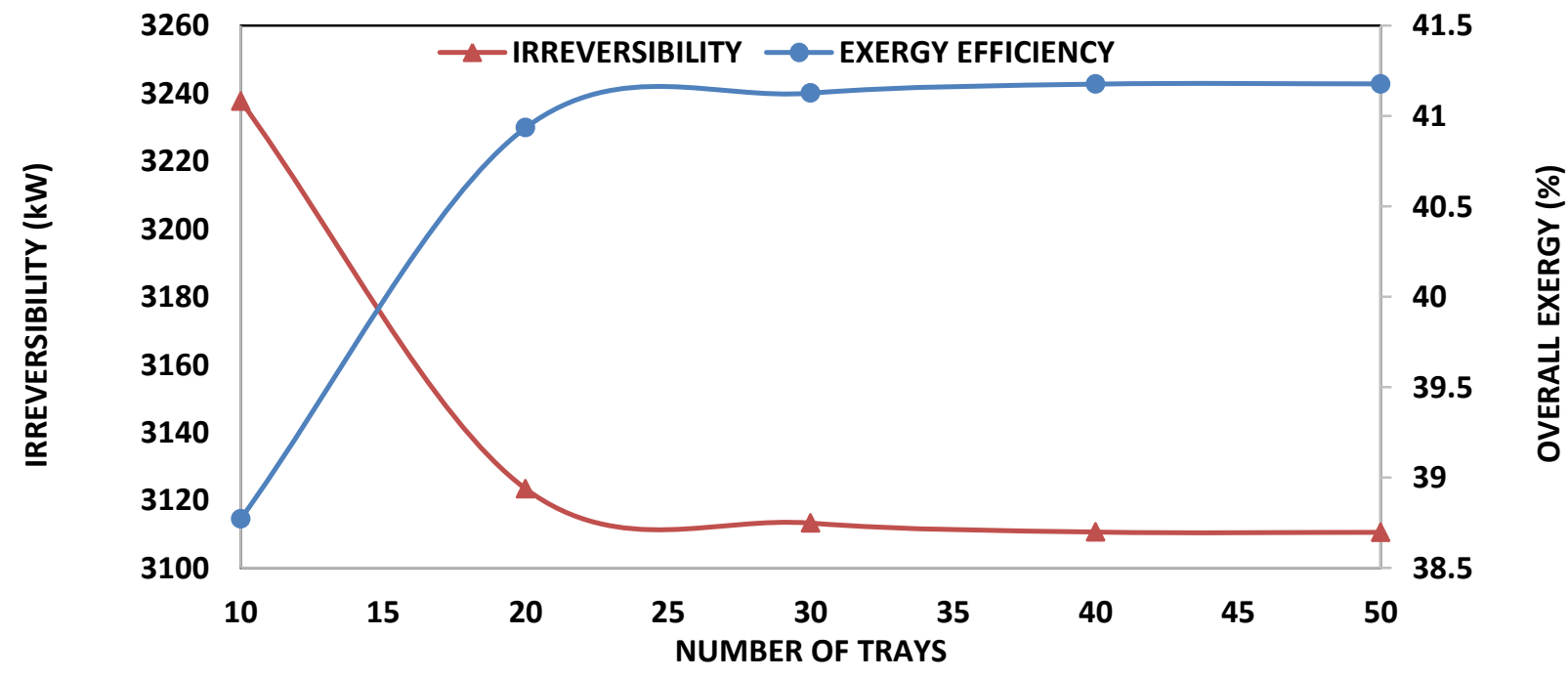

Figure 3: Effect of number of trays on overall exergy efficiency and irreversibility 


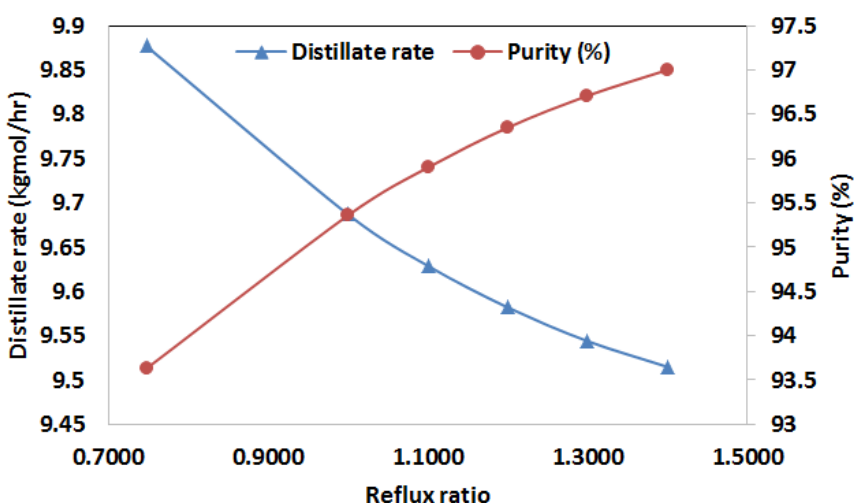

Figure 4: Effect of increasing reflux ratio on purity and distillate rate

Comparing results presented in both Figures 4 and 5 could enable design decisions. Methanol application where purity is of high importance (e.g synthetic dyestuffs, resins, drugs and perfume) would require operating the distillation column at high reflux ratio with its attendance high cost of operation in terms of energy cost. However, where methanol of low purity is desired in processes like production of fuel cells, injection into biodiesel to achieve high performance and in gasoline engines for an increase in power and a decrease in intake of air temperature in a process known as water methanol injection, then higher distillate rate should be a priority (i.e operating the column at low reflux ratio) because using high purity (high concentrations) methanol in fuel causes corrosion to some metals. For instance, methanol, although a weak acid, attacks the oxide coating that normally protects the aluminum in the gasoline engine from corrosion. Consequently, separation cost can be minimized by operating the distillation column at low reflux ratio if methanol of low purity is desired [27].

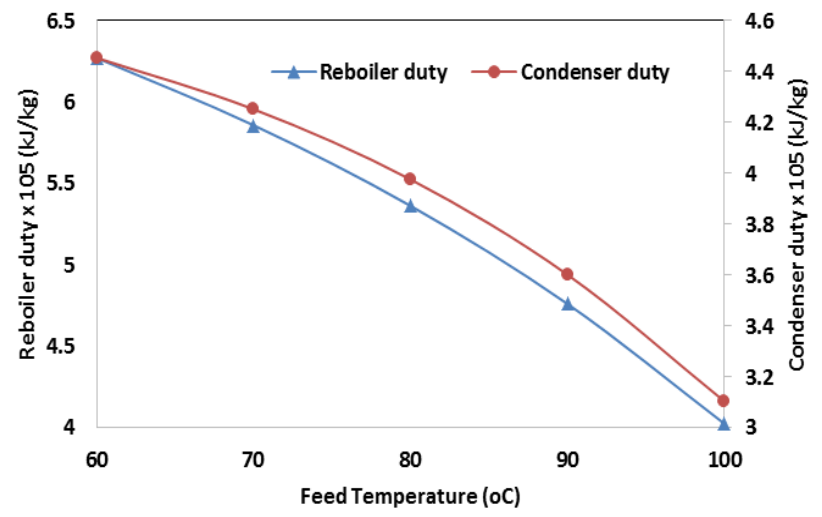

Figure 6: Effect of increasing feed temperature on reboiler duty and condenser duty

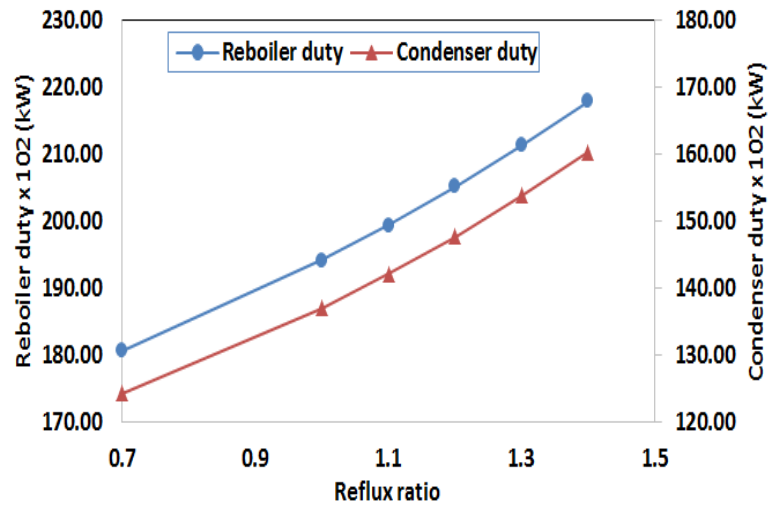

Figure 5: Effect of increasing reflux ratio on reboiler and condenser duties

\subsection{Effect of Increasing Feed Temperature on Distillate Rate, Methanol Purity and Energy Demand}

One of the major factors influencing the overall heat balance of a distillation column system is feed temperature. As shown in Figure 6, increasing the feed temperature reduces the reboiler heat duty and condenser heat requirement for energy balance within the column. When the feed temperature increased from 60 to $100^{\circ} \mathrm{C}$, the condenser heat duty reduced from $123.7 \mathrm{~kW}$ to $86.2 \mathrm{~kW}$, respectively while the energy requirement in the reboiler decreased from $174.2 \mathrm{~kW}$ to $111.8 \mathrm{~kW}$, respectively. Installing a feed pre-heater could be an economical design option to minimize reboiler heat duty.

As depicted in Figure 7, increased feed enthalpy reduces the required energy input from the reboiler at the same degree of separation [28]. Increasing the feed temperature which directly result in increasing feed enthalpy does not necessarily improve the overall efficiency of a distillation column when purity is of high priority but favours energy saving. Depending on the product specifications, careful review of feed temperature and phase is critical to minimizing overall energy consumption in the distillation process.

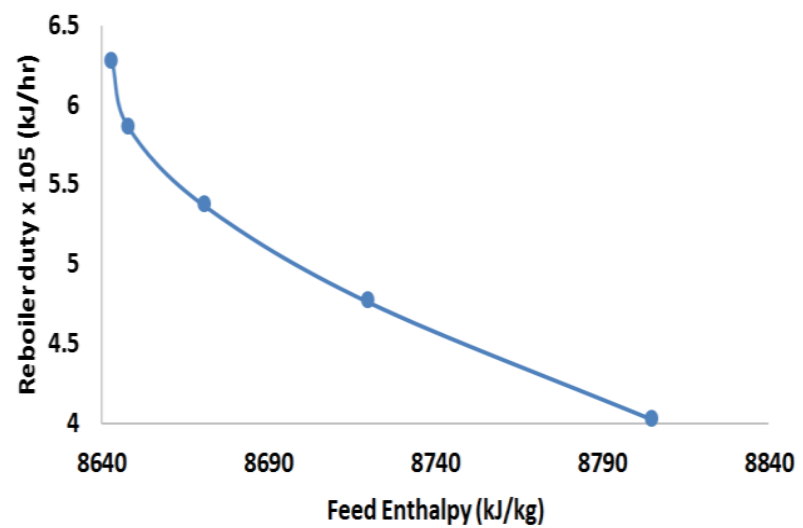

Figure 7: Effect of increasing feed enthalpy on reboiler duty 


\subsection{Results of Economic Analyses of the Methanol Plant} The results of variations of capital, energy and total costs with increasing number of trays are presented in Figure 8. It could be observed from the figure that the annualized capital cost of equipment increased with increasing number of trays. This is expected because the major equipment whose size is affected by increasing the number of trays is the distillation column. It is also observed from the table that the energy cost was reducing with increasing number of trays. This is because increasing the number of trays results in better separation, reduced reflux, and lower liquid flow to the bottom of the column and therefore lower reboiler duty to maintain vapour rate. Consequently, the total annual cost due to the trade-off between increasing capital costs and decreasing energy cost is minimized [29]. Further examination of Figure 8 showed that the total cost was minimum when the number of trays in the distillation column is 20. These number of trays are therefore considered to be the optimum number of trays at which this process can be run profitably. The plant produced 3100 metric tons of methanol per year and the current selling price of methanol is $\$ 255 /$ metric tons [9]. Hence, the net profit value accruable from the production is $\$ 4,081,157 /$ year when the total annualized energy cost is $\$ 1,610,443 /$ year and the capital cost for the methanol plant is $\$ 1,016,073$. The payback period for the process is estimated to be approximately 3 years.

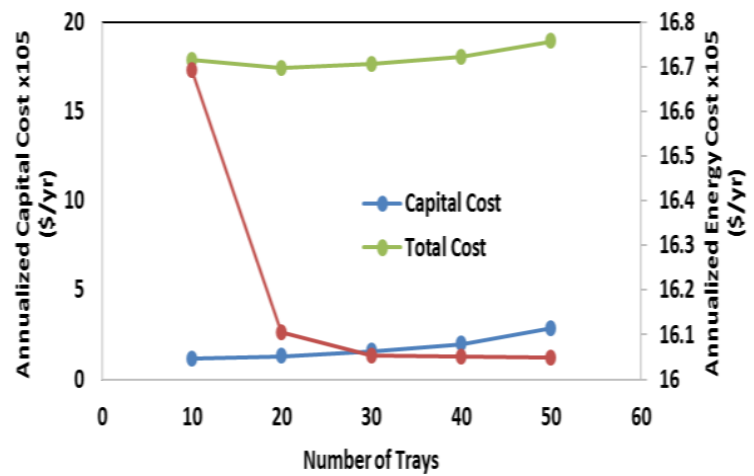

Figure 8: Effect of increasing number of trays on process costing

\section{CONCLUSIONS}

It was revealed from the study that the distillation column and auto thermal reactor are the major units contributing to the overall exergy destruction in the methanol production process. Hence, improving the performance of the unit is a way forward with respect to achieving better economic benefit of the process. Exergy and economic analyses methods were used to determine the optimum numbers of trays for the process and it was discovered from the two approaches that 20 trays gave the optimum performances in terms of exergy efficiency and operating cost benefits. The study concluded that locating such plant close to the thermal power plant where $\mathrm{CO}_{2}$ emitted from the plant could be captured and use as raw material could mitigate $\mathrm{CO}_{2}$ emissions from the plant.

\section{REFERENCES}

[1] Indala, S. 'Development and integration of new processes consuming carbon dioxide in multiplant chemical production complexes'. Published M.Sc. Thesis, Department of Chemical Engineering, Andhra University, India, 2004.

[2] Hasegawa, F., Yokoyama, S. and Imou, K. 'Methanol or ethanol produced from woody biomass, which is more advantageous?' Bioresource Technology, Volume 101, Issue 1, S109-S111, 2010.

[3] Huntley, M. E. and Redalie, D. G. ' $\mathrm{CO}_{2}$ mitigation and renewable oil from photosynthetic microbes: a new appraisal, Mitigation and Application Strategies for change'. Volume 12, No. 4, 573-608, 2007.

[4] Wee, J. H. 'Contribution of fuel cell systems to $\mathrm{CO}_{2}$ emission reduction in their application fields'. Renewable and Sustainable Energy Reviews, Volume 14, Issue 2, 735-744, 2010.

[5] Odejobi, O.J., Jisieike, C. F and Anozie, A. N. . Simulation and Exergy Analysis of Processes for $\mathrm{CO}_{2}$ Capture and Utilization for Methanol Production. Int. J. Exergy, Vol. 17, No. 4, 2015.

[6] Yusup, S., Anh, N. P. and Zabiri, H. 'A simulation study of an industrial methanol reactor based on simplified steady-state model'. IJJRAS, Vol. 5(3), 213-222, 2010.

[7] Esmaili, P. 'Thermodynamic analysis of an integrated photovoltaic system for hydrogen and methanol production'. Published M.Sc. Thesis, Department of Mechanical Engineering, University of Ontario institute of technology, Canada, 2012.

[8] Methanol Institute Methanol production [Online]. Available http://www.methanol.org/contentIndex.cfm?sect ion $=$ methanol\&topic $=$ factSheets\&titl e=Methpr (accessed 1 February 2015), 2015.

[9] PR Newswire Association . CMIA Completes 2010 World Methanol Analysis [Online]. Available at http://www.prnewswire.com/newsreleases/cmai-completes-2011-world-methanol- 
analysis-105860938.html (accessed 3 February 2015), 2015.

[10] Mignard, D., Sahibzada, M., Duthie, J. M. and Whittington, H. W. 'Methanol synthesis from fluegas $\mathrm{CO}_{2}$ and renewable electricity: a feasibility study'. International Journal of Hydrogen Energy, Vol. 28, Issue 4, pp. 455-464, 2003.

[11] Mar, P-F., Jan, C. S., Aikaterini, B., and Evangelos, T. 'Methanol synthesis using captured $\mathrm{CO}_{2}$ as raw material: Techno-economic and environmental assessment' Applied Energy 161:718-732, 2016.

[12] Marina, B., Thomas, L., Kevin, K., and Robert, S. 'Methanol Synthesis from Industrial $\mathrm{CO}_{2}$ Sources: A Contribution to Chemical Energy Conversion'. Catalyst Letter (2017) 147:416-427, 2017.

[13] Toyir, J., Miloua, R., Elkadri, N., E., Nawdali, M., Toufik, H., Miloua, F. and Saito, M. 'Sustainable process for the production of methanol from $\mathrm{CO}_{2}$ and $\mathrm{H}_{2}$ using $\mathrm{Cu} / \mathrm{ZnO}$-based multicomponent catalyst'. Physics Procedia, Volume 2, Issue 3, pp. 1075-1079, 2009.

[14] Marjani, A, Rezakazemi, M and Shirazian, S. Simulation of Methanol production Process and Determination of Optimum Conditions. Oriental Journal of Chemistry Vol. 28, No. (1): Pp 145-151, 2012.

[15] Dincer, I and Rosen, M. A. Exergy Handbook. Energy, Environment and Sustainable Ddevelopment. 2007.

[16] Szargut, J, Morris, D. R and Steward, F. R. Exergy analysis of thermal, chemical and metallurgical processes. New York: Hemisphere Publishing Corp, 1988.

[17] Moran, J. M Engineering Thermodynamics, Department of Mechanical Engineering, The Ohio State University, CRC Press Ltd, 1999.

[18] Lozano, M. A. and Valero, A. "Theory of the Exergetic Cost”. Energy, 18 (9): 939-960. 1993.

[19] Tsatsaronis, G. and Winhold, M. "Exergoeconomic Analysis and Evaluation of Energy-Conversion" Plants. 1: A New General Methodology. Energy, 10(1): 69-80, 1985.
[20] Cornelissen, R. L., "Thermodynamics and sustainable development". Ph.D. Thesis, University of Twente, the Netherlands, 1997.

[21] Anozie, A. N. and Odejobi, 0. J. 'The search for optimum condenser cooling water flow rate in a thermal power plant'. Applied Thermal Engineering, 31, 4083-4090, 2011.

[22] Sinnot, R. K. Chemical Engineering Design, $4^{\text {th }}$ edition, Elsevier Butterworth-Heinemann, USA, 2005.

[23] Modesto, M. and Nebra, S. A. 'Exergoeconomic analysis of the power generation system using blast furnace and coke oven gas in a Brazilian steel mill', Applied Thermal Engineering, vol. 29, pp.2127-2136. 2009.

[24] Tsatsaronis, G. and Cziesia, F. Exergy Analysis of Simple Processes. Vol. 1 Exergy, Energy System Analysis and Optimization, 2003.

[25] Coulson, J. M. and Richardson, J. F. . Particle Technology and Separation Processes, $5^{\text {th }}$ edition, Butterworth-Heinemann, USA. 2002. 2003.

[26] Dhar, B. R. and Kirtania, K. 'Excess methanol recovery in biodiesel production process using a distillation column: a simulation study'. Chemical Engineering Research Bulletin, 13, 5560. 2009.

[27] Zakaria, W. N.. 'Effect of reflux ratio on separation of azeotropic mixtures in batch distillation column'. Published B.Sc. Thesis, Department of Chemical Engineering, University of Malaysia. 2010

[28] Chukwuma, F. O. and Faniran, K.K. 'A simulation study of operating conditions of Straight Run Gasoline (SRG) Stabilizer column: A consideration of product recovery and energy saving options'. Journal of Emerging Trends in Engineering and Applied Sciences, 4 (5), 731-736. 2013.

[29] Kaymak, B. D., Yilmaz, D., Yilmaz, S., and Hosgor, E. 'Quantitative Comparison of Reactor/Column/Recycle Process with Reactive Distillation Column for Ternary Systems'. 20thEuropean Symposium on Computer Aided Process Engineering - ESCAPE20. 2010. 